\title{
The Formation of Trust and Commitment in Business Relationships in the Middle East: Understanding Et-Moone Relationships
}

\section{Abstract:}

In recent years, different forms of relationships that are culturally bond have emerged such as; 'Guanxi' in China (Yau, Lee, Chow, Sing, and Tse, 2000; Lou, 2007; Liu, Li, Tao and Wang, 2008), 'Blat' in Russia (Michailova and Worm, 2003) and 'Boon Koon' in Thailand (Pimpa, 2008). While these special forms of relationships are culturally bond, studies have also suggested that the development of a business relationship is directly linked to the development of trust and commitment (Wilson, 1995). Considering that these forms are culturally bond, studies from the Middle East on the formation of trust and commitment within relationship development are largely absent. We argue that understanding the dynamic formation of trust and commitment will help to better understand Et-Moone business relationships within the specific cultural context of the Middle East. Thus, this study combines the insights from the theory of life-cycle (Ford, 1980; Dwyer et al., 1987) and the theory of trust and commitment by Morgan and Hunt (1994) to understand business relationships in the Middle East. Based on qualitative research using a longitudinal approach and 33 semi-structured in-depth interviews conducted in 2003, this study finds the relationship between trust and commitment to be far more dynamic and changeable as the relationship evolves. Also, it finds that trust and commitment are major factors in establishing Et-Moone relationships.

Key Words: Trust, Commitment, Et-Moone Relationship, Life-Cycle Theory, Relationship Development, Saudi Arabia. 


\section{Introduction}

Relationship development has been described as the process of establishing, developing and maintaining relationships (Ford, 1980; Berry, 1983; Gronroos, 1994). Relationships develop between parties for different reasons. Parties seek to reduce uncertainty and/or add value (Hakansson, 1982). Parties invest in a relationship to gain a fair share of the increase in profits and to increase commitment (Anderson and Weitz, 1992). The core concept of relationship marketing is based on understanding trust and commitment (Morgan and Hunt, 1994; Palmatier et al., 2006). However, relationship marketing has proved to be contextually specific (industrial, service, customer) as well as culturally specific (Williams et al., 1998). Previous studies that examined the relationship development process did not pay attention to the role of culture as an important factor (e.g. Dwyer et al., 1987; Wilson, 1995). Equally, the developments of trust and commitment during different stages of the development process have not been empirically examined.

The conceptual process models of relationship development (e.g. Ford, 1980; Dwyer et al., 1987; Borys and Jemison, 1989; Wilson, 1995; Parvatiyar and Sheth, 2000) have adopted the life-cycle theory, which assumes relationship development goes through stage-by-stage deterministic and irreversible growth over time (Van de Ven, 1992). All these models are fundamentally describing the same development process and all are based on the same notion of life-cycle theory which has received much criticism for its unidimensional direction, discrete stages and inflexible time frame (Hedaa, 1993; Bell, 1995; Halinen, 1997; Stanton, 2002). These models represent a simplistic view of a rather complex dynamic of relationship development. It 
is accepted that relationship development "can move forward and backward or even stay in the same state for an undetermined period" (Rao and Perry, 2002, p. 604). Thus, precise prediction that captures the true nature of the movement of relationship over time is difficult. However and despite this difficulty, researchers have to unveil the implicit rules that influence individuals' relational behaviour that brings about the movement on the sequential stage of relationship development (Weitz and Jap, 1995); set the relationship norm (Heide and John, 1992); influence the perceived value of the relationship (Levitt, 1983); influence the nature of relational constructs; and influence the time element of the movement from one stage to the next. We argue that by combining the insights from the theory of life-cycle (Ford, 1980) and the theory of trust and relationship commitment (Morgan and Hunt, 1994) within the Saudi Arabian cultural context of a B2B relationship can help in understanding much of the dynamic development of business relationships that leads to the development of the special 'Et-Moone' relationships in Saudi Arabia and possibly other Arab countries.

Using the life-cycle framework (pre-relationship, early interaction, growth, and maintenance stages), this paper seeks to understand factors contributing to the formation of trust and commitment and their influence on the development of 'Et-Moone' relationship. Business relationships are found to be influenced by cultural orientations (Williams et al., 1998), which can determine the social and emotional superstructure of business relationships (Cova and Salle, 2000). The Saudi Arabian culture is described as one of the ancient cultures (Gronroos, 1994), in that relationships are essential to commercial exchanges. Recent evidence indicates that the Saudi market has already moved from sellers' conditions to buyers' conditions (Leonidou, 1996), reinforcing the importance of relationship in the exchange. Yet, the literature is largely absent on the nature of relationships and their development in Arab countries. This represents a significant 
lacuna in the debate on relationship marketing, not least because of increasing global interdependence with Arab countries but also due to paradigmatic shifts in how relationship dynamics are conceptualized. To fulfil this gap, empirical research was conducted among managing directors from top Saudi firms using semi-structured interviews in 2003 then repeated with the same managers in 2007/08. Informants provided useful depth on the role of interpersonal and organizational relationships in the formation of trust and commitment and the development of Et-Moone relationships.

\section{The Context for Empirical Research}

The Saudi Arabian cultural and economic settings provide an opportunity to explore relationship development from an ancient perspective where the interpersonal and organizational relationship is of fundamental importance to the success of business exchanges. Unlike Western countries where relationship marketing was rediscovered in the post-industrial revaluation (Sheth and Parvatiyar, 1995), relationships continue as they have always been to facilitate parties' exchanges in the Saudi context. It is argued that the logic of buyer-seller interactions known in the current literature on relationship marketing may be different from those that exist in an Eastern culture (Ohame, 1989) such as in Saudi Arabia. The literature has already provided evidence of different form/type of unique relationship that exist in Eastern cultures such 'Guanxi' in China (Yau, Lee, Chow, Sing, and Tse, 2000; Lou, 2007), 'Blat' in Russia (Michailova and Worm, 2003) and 'Boon Koon' in Thailand (Pimpa, 2008). As Czinkota et al. (1999, p. 36) argued that Saudi Arabia is one Eastern country where the traditional way of doing business remains largely unchanged, yet, studies focusing on the Gulf States and in particular 
Saudi Arabia are limited. The context is interesting because the business community in Saudi Arabia traditionally does not distinguish between marketing activities and the maintenance of relationships. Thus, interpersonal relationships are always viewed as essential in the buyer-seller exchange in Saudi Arabian business relationships. Business relationships are principally based on interpersonal interactions with a considerable emotional component which is not appreciated by firms (Sheaves and Barnes, 1996). The B2B relationships in Saudi Arabia are represented by over $90 \%$ of businesses that are traditionally owned, and in most cases managed, by a single family. Thus, the social exchange theory within the Saudi context, which exclusively deals with interpersonal relationships, would be more influential than the commercial context in parties' interaction.

\section{Relationship Development}

In broader terms, relationship development has been described as the process of establishing, developing and maintaining relationships (Ford, 1980; Berry, 1983; Gronroos, 1994). Based on the social exchange theory, models developed over the last three decades described a largely similar development process of relationships (for summary of these studies see Appendix A). Ford (1980) conceptualized relationship development in five stages: a prerelationship stage, an early stage, a development stage, a long-term stage, and a final stage. Dwyer et al. (1987) identified similar development stages: awareness, exploration, expansion, commitment and dissolution. Taking a pragmatic view, Wilson (1995) conceptualized the relationship development process in terms of the functionality of each stage as partner selection, defining purpose, setting relationship boundaries, creating relationship value and relationship 
maintenance. Also, Wilson's (1995) model described not just a sequence in relationship development but also content at each stage, outlining the role of relational constructs such as trust, commitment and cooperation in each stage. Crucially, these models are generally underpinned by assumptions that, with an increasing level of information, relational agents become increasingly committed and likely to progress to the next stage.

The pre-relationship stage starts when partners hear or gain knowledge about one another. It also relates to any activities (e.g. change in the marketplace) that lead to partners realizing the need for a new partner for their firms (Wilson, 1995). The selection of a partner is critical and once it is done the relationship can move to the next stage. The early interaction stage involves the trial and testing of the new partner. Most of the interactions occurring during this stage focus on improving partners' learning about the relationship in an effort to reduce relationship uncertainty (Dwyer et al., 1987). The growth stage involves intensive interaction and adaptation between partners (Ford, 1982; Dwyer et al., 1987). The maintenance stage is characterized by partners' mutual importance to each other where they have made an implicit or explicit pledge to continue their relationship (Dwyer et al., 1987). The relationship termination stage is where partners end the relationship. The relationship can be terminated at any stage. However, recent studies (e.g. Batonda and Perry, 2003) on relationship development have started to question whether or not relationships actually do end. Batonda and Perry (2003) argued that the cycle of relationship development has no end since relationships can be reactivated. In recent years, studies on relationship development appear to focus solely on one single stage within the development process. For example, some studies focused on relationship maintenance (Harris et al., 2003; Fletcher and Harris, 2012), whereas other studies focused on relationship dissolution (Halinen and Tahtinen, 2002; Pressey and Mathews, 2003). 
Importantly, the process of relationship development is strongly associated with key relational constructs development, mainly trust (Anderson and Weitz, 1989; Anderson and Narus, 1990; Ganesan, 1994; Morgan and Hunt, 1994), and commitment (Dwyer et al., 1987; Moorman et al., 1992; Gundlach and Murphy, 1993; Morgan and Hunt, 1994). Moreover, Williams et al. (1998) found the drivers of trust and commitment vary in different cultural contexts.

\section{Trust}

Trust has been defined as "the willingness of a party to be vulnerable to the actions of another party based on the expectation that the other will perform a particular action important to the trustor, irrespective of the ability to monitor or control that other party" (Mayer et al., 1995, p. 712). Trusting other parties provides the basis for assessing predictability of future behaviour based on past interaction and promises (Doney and Cannon, 1997; Boersma et al., 2003), reducing uncertainty (Crosby et al., 1990; Morgan and Hunt, 1994), reducing the perception of risk associated with opportunistic behaviour (Dwyer et al., 1987; Morgan and Hunt, 1994), and undermining formalizing decision making (Fang et al., 2008). Trust allows the development of flexible structures (Zaheer and Venkatraman, 1995) and for positive expectations (Moorman et al., 1992; Das and Teng, 1998). Trust increases satisfaction (Smith and Barclay, 1997), initiates parties' propensity to stay in the relationship (Anderson and Weitz, 1989; Mohr and Spekman, 1994), fostering cooperative intention (John, 1984; Morgan and Hunt, 1994; Smith and Barclay, 1997; Joshi and Stump, 1999; Harris and Dibben, 1999; Keh and Xie, 2009), influencing parties' long-term orientation (Ganesan, 1994; Lai, Pai, Yang and Lin, 2009), and building relationship commitment (Gundlach et al., 1995). Overall, trust acts as a driver of the relationship as long as 
it stresses the intention of cooperating, and increases the parties' expectations of continuity (Anderson and Weitz, 1989; Andaleeb, 1996). Trust is an overtime accumulative development from various sources that drive the relationship along the process of relationship development.

Competence trust refers to "the expectation that partners have the ability to fulfill their roles" (Lui and Ngo, 2004, p. 474). Importantly, competence trust requires a shared understanding of professional conducts, vision and technical and managerial standards ( $\mathrm{Li}, 2005)$. The shared formation of rules and procedures in the relationship as well as the explicitly/implicitly communication of capabilities can effectively develop competence trust and foster coordination (Mayer et al., 1995; Levin and Cross, 2004; Hausman and Johnston, 2010). It affects the perceived usefulness of shared knowledge and information (Levin and Cross, 2004), reduces the perceived risk of inadequate performance by a partner (Das and Teng, 2001), increases partner's integrity and reliability (Morgan and Hunt, 1994) and increasing liking in the relationship (Walther and Bunz, 2005). The study by Das and Teng (2004) shows the formation of competence trust is contextual as well as culturally specific. Similarly, Nes et al. (2007) found the national culture to influence the nature of trust differently.

Affective-based trust is the confidence a party places in another party based on the feelings and emotions generated by the caring, empathy, politeness, similarity, and concern for the other party demonstrated in their interaction (Rempel et al., 1985). Affective-based trust is characterised by "feelings of security and perceived strength of the relationship" (Johnson and Grayson, 2005, p. 501), interpersonal liking (Nicholson et al., 2001), and a 'leap of faith' beyond the expectations that reason and knowledge would warrant (Wicks et al., 1999, p. 100). This type of trust is motivated by a partner's goodwill (Miyamoto and Rexha, 2004), reputation (Einwiller, 2003), actions/behaviours (Rempel et al., 1985), shared values (Morgan and Hunt, 1994), norms 
(Heide and John, 1992; Gundlach and Murphy, 1993), and benevolence and emotion (Ganesan, 1994; Andersen and Kumar, 2006).

\section{Relationship Commitment}

Commitment has been defined as "an enduring desire to develop and maintain exchange relationships characterised by implicit and explicit pledges and sacrifices for the long-term benefit of all partners involved" (Rylander et al., 1997, p. 60). Instrumental/calculative commitment is viewed as a function of pledges, idiosyncratic investments, sharing of information, and allocation of relationship-specific resources (Anderson and Weitz, 1992; Gundlach et al., 1995; Lehtonen, 2006; Sivaramakrishnan et al., 2008). Inputs or investments in a relationship are evidence and manifestation of implementing early promises which enhance parties' credibility at the beginning of the relationship and reduce uncertainty and the risk of opportunism (Morgan and Hunt, 1994; Achrol and Gundlash, 1999; Wuyts and Geyskens, 2005). Sandy and Ganesan (2000) examined the role of specific investment on developing commitment during a relationship life-cycle. They found that the transaction-specific investment enhances commitment in the exploration phase and has a positive effect during the decline phase. These inputs or investments into the relationship act as barriers against one party leaving the relationship, as it becomes more costly to terminate the relationship (Morgan and Hunt, 1994; Abdul-Muhmin, 2005).

Affective commitment is the result of emotional bonds that may drive parties to maintain and improve the quality of their relationship (Bendapudi and Berry, 1997; Fletcher et al., 2000). Thus, a social structure is generated through individuals' desire to be psychologically and emotionally consistent throughout the interaction (Meyer and Allen, 1991). During this process 
managers identify shared values and goals of their organizations to which they are psychologically attached (Gundlach et al., 1995; Ripolles et al., 2012). According to this view, committed partners desire to continue their relationship because they like and enjoy the relationship (Jaros et al., 1993; Vandenberghe and Tremblay, 2008; Cater and Cater, 2010).

\section{Research Design}

Since little is known about the development and maintenance of relationships in the Saudi context, an exploratory qualitative research was designed. In-depth interviews were employed because they allow for rich insights and meanings to be obtained (Fontana and Frey, 2000) and because "the influences of the local context are not stripped away, but are taken into account" (Miles and Huberman, 1994, p. 10). Thus in-depth interviews have the ability to enable the managers to give a detailed discussion of the complex and dynamic development of relationships (Ghauri and Gronhaug, 2010). The interviews were informal and more like "a conversation with a purpose" (Burgess, 1984, p. 102). Semi-structured interviews contained open-ended questions to allow informants to express their views in their own words. A broad guide of each interview was produced to ensure that issues of interest were uncovered (Holstein and Gubrium, 2004).

\section{Data Collection and Analysis}

Managers were selected to reflect the business to business (B2B) relationships in the manufacturing industry in Saudi Arabia. The interviews were conducted with the same managers, 
first in 2003 and then repeated in 2007/08. Eighteen interviews were conducted in 2003 with managing directors of the top Saudi manufacturing firms. Selected managers were approached in two phases. The first phase was based on the advice offered by an influential member of the Saudi business community. In the Saudi culture such overt personal sponsorship and personal introductions are essential to gain access, and reduce the negotiation period over access to a manageable interval. By using this method, it was possible to gain access to seven managing directors. Four informants were the managing directors of family-owned companies and two were members of the owning family. The other three informants were the managing directors of public companies (multiple ownerships). Table 1 contains full details of phase one of the interviews. On average, each interview lasted for about $1.5 \mathrm{hrs}$.

Table $1 \quad$ Summary of the Interviews in Phase One in 2003

\begin{tabular}{|l|c|c|c|c|}
\cline { 2 - 5 } \multicolumn{1}{l|}{} & \multirow{2}{*}{ Position } & Activities & Company Status & Company \\
\hline Interview No. 1 & 8 Years & Containers Manu. & Family-owned & Large \\
\hline Interview No. 2 & 6 Years & Plastics Manu. & Family-owned & Large \\
\hline Interview No. 3 & 5 Years & Multiple sectors & Family-owned/ & Large \\
\hline Interview No. 4* & 1 Year & Food Manu. & Public & Large \\
\hline Interview No. 5* & 7 Years & Import and trading in manu. & Public & Large \\
\hline Interview No. 6 & 4 Years & Foods & Public & Large \\
\hline Interview No. 7 & 10 Years & Service provider to & Family-owned/ & Medium \\
\hline
\end{tabular}




\begin{tabular}{|l|l|r|r|r|}
\hline & & $\begin{array}{r}\text { manufacturing firms (projects } \\
\text { management) }\end{array}$ & \\
\hline
\end{tabular}

* These two managers were not interviewed in 2007/08. Both have left their companies.

To understand the development of relationships over time, phase two was planned where access was negotiated directly with 11 managing directors in 2003 . The average time for each interview was 45 minutes. However, the insight gained in phase one helped to get 'right to the point'. Managers were drawn from seven family-owned companies (five of them were managed directly by the family and two were managed by non-family members) and four from public companies. Table 2 shows information on the selected sample in phase two.

Table 2 Summary of the Interviews in Phase Two in 2003

\begin{tabular}{|l|c|c|c|c|}
\cline { 2 - 5 } \multicolumn{1}{l|}{} & Position & Activities & Company Status & Company \\
\hline Interview No. 1* & 4 Years & Furniture Manu. & Family-owned/ & managed \\
\hline Interview No. 2 & 3 Years & Plastics Manu. & Public & Large \\
\hline Interview No. 3 & 5 Years & Steel & Family-owned/ & Large \\
\hline Interview No. 4 & 5 Years & Manu. & Famaged & Large \\
\hline Interview No. 5 & 2 Years & Petrochemical Manu. & Public & Large \\
\hline Interview No. 6* & 3 Years & Plastic Manu. & Public & Large \\
\hline Interview No. 7 & 7 Years & Food Manu. & Family-owned/ & Medium \\
\hline
\end{tabular}




\begin{tabular}{|l|c|c|c|c|}
\hline & & & managed & \\
\hline Interview No. 8 & \multirow{2}{*}{1 Year } & Food Manu. & Family-owned/ & Medium \\
& & managed & Public & Large \\
\hline Interview No.9 & 3 Years & Food Manu. & Family-owned/ & Large \\
\hline Interview No. 10 & 5 Years & Building materials Manu. & managed & Large \\
\hline Interview No. 11 & 2 Years & Food/Drink Manu. & Family-owned & \\
\hline
\end{tabular}

$*$ These managers were not interviewed in 2007/08. They did not agree to take part in the interview.

During 2007/08, fifteen interviews were conducted again with the same managing directors from both phases in 2003 with the exception of three managers who did not take part in the study in $2007 / 08$ (total interviews in this study 33). The interviewer asked largely the same questions as in 2003. In order to trackback the development and changes in their business relationship since 2003, interviewees were instructed to refer their answers to the same business partner in 2003. This was important in order to understand the dynamic changes that may have happened to trust and commitment over the years. However, managers spent most of the time talking about the growth and maintenance stages. This was expected, given the knowledge already gained on the history of their business relationships from 2003.

Two levels of data analysis were conducted following Miles and Huberman (1994) and Ghauri (2004). Each interview was immediately reviewed by the researcher, where constant themes were identified and new issues highlighted. A rough descriptive story from each interview was sent to the respective manager for their confirmation. Each interview was then compared with previous ones to identify similarities and differences. The second stage involved 
coding the data and developing the researcher's understanding of the related subject. Interviews were analyzed using open coding where line-by-line analysis was conducted (Sandelowski, 1995). As a result, a few categories and themes appeared that were discussed with four academics and four managers. Only themes and categories that achieved full agreement among the four academics have been maintained and are presented in this paper. Thus, the findings of this study are credible and trustworthy, whereby academics and practitioners validated procedures undertaken by the researchers (Sinkovics et al., 2008).

\section{Findings}

The interviews generated rich data. It was challenging to seek patterns and draw conclusions. We present the findings and present meaningful quotations to strengthen our interpretations. In order to show the formation of trust and commitment during the development stages, each stage is discussed separately, together with the relevant findings.

\section{Pre-Relationship Stage}

Our findings show that partners are involved in a process of searching for a sign of trustworthiness. Thus, we call this stage 'search trust'. This form of trust occurs when managers start gathering information about the trustworthiness of a potential new supplier.

“We don't take a supplier straightaway; we do our research about his trustworthiness, reputation in the market, and what type of person he is." (Fahad) 
The data show that this form of trust is underpinned by three main factors. The first type of information that influences this form of trust is a 'third party's' recommendations regarding a potential new supplier. The third party can be a friend, an existing supplier or a competitor.

"When someone recommends a supplier to me, I ask 'Who is he? Who is his family?

What do they know about him? How is he known with his customers?" (Ali)

The second type of information is related to the 'social reputation' of the potential new supplier. Key elements of this are family reputation, social behaviour, similarity, liking, etc. While some of these elements are quite easy to find (e.g. family reputation and social behaviour), other elements such as similarity and liking need some sort of direct interaction between the manager and the supplier.

"Yes, yes, yes because you expect that a person from a respected family will be very trustworthy and frank with you. He will try his best to respect the reputation of his family." (Ahmed)

The third type of information is related to 'performance reputation' of the potential new supplier. The research for a new supplier primarily arises from a firm's business needs. Thus, finding the right supplier to perform what is needed for a company is important. While family reputation acts as protection, performance reputation acts as reassurance of fulfilling the main need of creating a new relationship with a new supplier.

"Initially reputation of the supplier is the most important factor in dealing with any supplier. I may like to deal with a 'shining' name but it isn't necessarily the only factor." (Khalid) 
Thus data show that this form of trust has three antecedents: third party advice, social reputation and professional reputation. The total trust gained during this stage helps the buyer to select a supplier.

\section{Early Interaction Stage}

Our findings suggest that, within this stage, there are three forms of trust that contribute to the amount of trust established in the relationship. The overall trust established during this stage can be described as 'trial trust' because components of 'trial trust' emerged as a result of parties scrutinizing each other on different levels. The first form of trust is based on 'personality'. The characteristics of individuals are important in establishing a relationship and dealing with future changes. Personal values and similarities lead to parties liking to interact with each other (Nicholson et al., 2001), which leads to a stronger social bond that "tend[s] to hold relationships together" (Wilson, 1995, p. 339). The findings show that personal traits of parties are very important, particularly at an early stage where uncertainty and distance exist.

"The socialization of the supplier tells you if the supplier is serious about you and it tells you a lot about himself, what kind of man he is." (Fahad)

The second form of trust is based on 'contracts'. Contracts are drawn up to provide protection and establish safer ground for the initial commercial interaction. The data support the argument by Seshadri and Mishra (2004) that contracts are complementary to a relationship and provide a governance structure for relationships. This seems to be the case with Saudi managers 
who agree on the importance of a contract but at the same time they constantly emphasize that contracts should not be at the centre of their interaction.

"Contracts are important but if the contract becomes the centre of our exchange then it will be difficult for the relationship to be flexible enough and may cost us a lot, but a personal relationship ('personal contract') smoothes everything ... we tend not to look at what the formal contract said." (Ahmed)

The third form of trust that emerges during the early interaction is 'early competence'. This refers to an early level of competence of business exchange between parties where parties experience the performance of each company for the first time.

"A new supplier is always anxious to satisfy you in the short-term but you should always be on the look-out for consistency in his performance." (Saleh)

These types of trust contribute to the accumulative trust in the relationship until the point of the development process which transfers to the next stage of development. Figure 1 below shows the three types of trust formed during this stage.

\section{Growth Stage}

The level of trust accumulated from the pre-relationship stage and the early interaction stage determines whether or not partners will reach the relationship growth stage. If the relationship continues to reach this stage then it has passed the major obstacles. Managers focus their assessment during this stage on full competence in each other's performance. 'Competence 
trust' is the final condition for full trust in the relationship. The findings suggest that there are two ways in establishing competence trust. The first way occurs when partners perform as expected or as promised by them during the early interaction stage. Thus, partners use the actual performance to assess competence.

“A supplier's performance and professionalism in doing his business tell me if he is trustworthy and deserves staying with him or not." (Faisal)

The second way occurs when partners do 'small things/favours' in the exchange which are not expected and yet are very effective in increasing partners' competence trust in the relationship. This way also acts as an indicator of the other party's competence in meeting their promises and still being able to do 'small things' for their partner.

"Small things help, like discount when you don't expect it, good information about the market or our performance." (Khalid)

Without competence trust in the relationship at this stage, relationship commitment would not exist. In order to be fully committed to the relationship, parties assess the benefits and costs of their involvement in the relationship. Thus, when both realize 'mutual benefits' then the relationship is solidly established. The data suggest that partners are mutually looking to benefit each other. Managers understand that without mutuality they cannot maintain the relationship.

"In the relationship you need to hold the stick from the middle in a way where you maintain the benefits of both sides and maintain the confidence both sides 
Maintenance Stage

Recent literature has indicated that mutuality needs to be reciprocated in kind by parties (Gao et al., 2005). In the case of Saudi managers, business benefits combined with personal appreciation are the main determinants of a strong relationship.

"The long-term future of my relationship with my supplier is driven by our respect for each other and maintaining the standard of our performance." (Saleh)

Managers during this stage develop a strong bond and likability over the time of interaction as a result of a number of factors such as family reputation, personality traits, personal appreciation, competency trust, mutual benefits, and personal commitments. The 'gratitude dynamic' outcome of all of these is a long-term commitment by both partners during which the relationship is characterized by flexibility, mutual care of the long-term well-being of the relationship and appreciation of social and business benefits both partners enjoy. The commitments by partners escalate each commitment to maintain the relationship.

"I look after the relationship with him because he is a man with values, keeps his word and I trust him on my own business; I allow him to make decisions that he likes." (Saleh)

This high commitment combined with total trust and high level of likability can lead to the development of an Et-Moone relationship, which is probably unique to the Saudi business context. Managers use the term 'Et-Moone' to describe the different kind of relationship with some of their business partners. The concept of Et-Moone was originally used at the social level 
where using this term allows each partner greater space and power in the relationship without necessarily asking for permission.

"I Et-Moone on my supplier and so does he; he is a man with high integrity and he can have anything he wants, unquestionably." (Majid)

Most managers have repeatedly emphasized that Et-Moone is the result of long-term interaction and friendship which enable managers to develop a strong commitment and greater flexibility and likability.

"I will be flexible with the one whom I trust. The one whom will not deliver for a good reason and the one whom I Et-Moone on and he Et-Moones on me." (Sami) "I'm most committed to those whom I Et-Moone on, who have been with me for a long time and have been consistent with me." (Ali)

Unlike normal relationships where mutuality is important to the future of relationships, Et-Moone's partners do not necessarily expect immediate or even future return on their actions. While this needs more exploration, as suggested below:

"You always need to be prepared to help your real friend who Et-Moone on you. If he is in bad situation and need more helps then you shouldn't expect any return on your helps" (Faisal)

Et-Moone relationships are very few in any manager's life. This may be because of the high level of investments required to gain a strong 'liking' between managers.

"Not everyone can Et-Moone. You know this; when he is a good person, trustworthiness, honesty and consistency are important." (Saud) 


\section{Discussion}

This paper sets out to integrate two streams of research on relationship marketing. The relationship life-cycle theory, presented by Ford's (1980) and Dwyer et al.'s (1987) work, that describes the process development of relationships. The other stream is related to Morgan and Hunt's (1994) work on trust and commitment. The combination of both research areas has brought insights into modelling the dynamic formation of trust and commitment, especially the role of the cultural context of relationships in the dynamic nature of business relationship development. The findings suggest that trust, in particular, should not be defined in isolation of the cultural context in which business relationships are embedded. Thus, culture can help explain not only how relationships and their core constructs (e.g. trust and commitment) develop but also why the development occurs. Furthermore, culture influences the speed of development and acceleration of the formation of trust, especially at the early interaction through effective communication and clearer and manageable expectations which affect the future growth of trust.

The relationship between trust and commitment is dynamic as relationships need to grow and at the same time need to be maintained. Thus, the continuous movement from growth to maintenance and vice versa means trust and commitment can be the antecedent and outcome of each other. This explains the contradictory relationship between the two constructs where trust was found to influence commitment (e.g. Anderson and Weitz, 1989; Morgan and Hunt, 1994; Andaleeb, 1996; Ruyter et al., 2001) and commitment was found to influence trust (e.g. Aulakah et al., 1996; Havila et al., 2004; Miyamoto and Rexha, 2004; Gao et al., 2005). Furthermore, 
relationship development is not limited to only one stage of growth but rather it can have many 'growth' stages and similar 'maintenance' stages. While this finding contradicts with the core essence of the life-cycle theory, which describes the development of going through deterministic, irreversible growth over time and an inflexible time frame (Van de Ven, 1992; Hedaa, 1993), our finding, by focusing on the formation of trust and commitment instead of the stage development of relationship, provides better insights to the dynamic nature of relationship development, overcoming some of the major weaknesses of the life-cycle theory (e.g. Halinen, 1997; Stanton, 2002). In addition, the linear assumptions that underpinned the adoption of life-cycle have not helped in understanding the true dynamic nature of relationship development which often separates it from its cultural context which is essential to understanding the dynamic perspective of relationship development.

The concept of Et-Moone emerged as a distinctive concept lying at the heart of which is a strong friendship and appreciation. In sharp contrast to the Western perspective of relationship marketing, Asian relationships evolve around personal relationships (Wang, 2007). Kriz and Fang (2003) found business relationships in Asia to focus on terms such as 'friendship', 'social reputation', and 'personal recognition'. Yan et al. (2000) found Asian managers to be more willing to honour a deal as long as the friendship is more valuable than the deal itself. However, while some of the findings from our study are similar to those studies, the concept of Et-Moone can allow unilateral decisions in the relationship without alienating partners or damaging the relationship. The unilateralism in decision making would depend on the informal agreement explicitly or implicitly communicated within the classic high-context fashion (Hall, 1973).

Et-Moone can be understood in terms of 'empathy', 'liking' and 'gratitude', and not necessarily (on some occasions) 'reciprocity' as in the Chinese relationships (Wang, 2007) 
where a partner should repay the debt of a specific favour (Wang et al., 2008). Empathy means understanding a situation from a partner's point of view and providing emotional and financial support as needed. The greater the level of empathy in a relationship, the more likely partners are to reduce barriers to the relationship and increase their affective connection. Liking refers to the overall attachment and comfort in a relationship. The ability to get on with one another and the enjoyment of close interpersonal interaction can increase the level of liking in a relationship. Gratitude refers to the feeling of gratefulness and appreciation of a partner's empathizing and sympathizing with past problems or situations during which the partner provides help and proves 'to be there as a friend'. Gratitude increases and enhances liking in a relationship and is the result of the overall quality of interaction. Reciprocity is important during the growth of a relationship. However, while it is still important when an Et-Moone relationship is established, over time reciprocity will become less important as partners do not want to receive a return or a repayment each time they do a favour. The combination and the quality of 'empathy', 'liking', 'gratitude' and 'reciprocity' would determine whether or not partners can accept unilateralism in their relationships.

\section{Conclusion and Future Research}

This study has focused primarily on understanding the formation of trust and relationship commitment during the development stages of relationships in Saudi Arabia. By combining the theory of trust and commitment and life-cycle theory, the dynamic perspective of relationship marketing in Saudi Arabia has been better understood. Unlike Western understanding of relationships, in Saudi Arabia personal relationships are critical in the development of trust and 
relationship commitment. Social and professional reputations and third party's advice generate trust in the pre-relationship stage. Contracts, initial performance and personal liking are the key factors in driving trust generated by partners' initial interaction. In the growth stage, competence trust is developed through performing as expected and doing extra small favours. As a result of establishing competence trust, mutual benefits indicate partners' initial commitment, which typically will be a calculative commitment. The combination of accumulated trust, calculative commitment and personal liking is the key antecedent of affective commitment and full relationship commitment leading to a long-term relationship where partners have the will to maintain the relationship. The Et-Moone concept has been found to influence business relationships and it is the outcome of total trust, relationship commitment and a high level of relationship likeability.

Our study suggest that Et-Moone has four important factors that lead to the creation of an Et-Moone relationship: (1) positive past interaction; (2) trust and strong relationship commitment; (3) strong personal friendship characterized by high levels of empathy, liking and reciprocity; (4) mutual acceptance of power sharing and decision making. Different managerial implications can be concluded from this study. Considering the importance of trust and relationship commitment in the development of these relationships, managers can adopt a number of strategic thoughts focusing on building, improving and maintaining trust and relationship commitment.

Whilst this research has important implications for developing and maintaining relationships in Saudi Arabia and the Middle East, further research is needed to examine a variety of issues. Furthermore, future research could use the quantitative approach to test some of the findings generated by this study. Et-Moone is probably unique not only to Saudi Arabia but 
to other Middle Eastern countries. Future research should study this important construct in other Middle Eastern countries.

\section{References}

Abdul-Muhmin, A. G. (2005). Instrumental and interpersonal determinants of relationship satisfaction and commitment in industrial markets. Journal of Business Research, 58(5), 619-28.

Achrol, R. \& Gundlach, G. (1999). Legal and social safeguards against opportunism in exchange. Journal of Retailing, 75(1), 107-124.

Andaleeb, S. (1996). An experimental investigation of satisfaction and commitment in marketing channels: the role of trust and dependence. Journal of Retailing, 72(1), 77-93.

Andersen, P. \& Kumar, R. (2006). Emotions, trust and relationship development in business relationships: A conceptual model for buyer-seller dyads. Industrial Marketing Management, 35 (4), 522-535.

Anderson, E. \& Weitz, B. (1989). Determinants of continuity in conventional industrial channel dyads. Marketing Science, 8(4), 310-324. 
Anderson, E. \& Weitz, B. (1992). The use of pledges to build and sustain commitment in distribution channels. Journal of Marketing Research, 29(1), 18-35.

Anderson, J. \& Narus, A. (1990). A model of distributor-firm and manufacturer-firm working partnerships. Journal of Marketing, 54(1), 42-58.

Aulakh, P., Kotabe, M. \& Sahay, A. (1996). Trust and performance in cross-border marketing partnerships: a behavioural approach. Journal of International Business Studies, 27(5), 10051032.

Batona, G. \& Perry, C. (2003). Influence of culture on relationship development process on overseas Chinese/Australian networks. European Journal of Marketing, 37(11/12), 1548.

Bell, J. (1995). The internationalisation of small computer software firms: a further challenge to “stage" theories. European Journal of Marketing, 29(8), 60-75.

Bendapudi, N. \& Berry, L. (1997). Customers' motivations for maintaining relationships with service producers. Journal of Retailing, 73(1), 15-37.

Berry, L. (1983). Relationship marketing. In Christopher, M., Payne, A., Clark, M. and Peck, H. (1997), Relationship Marketing for Competitive Advantage. Oxford: Butterworth-Heinemann, $65-74$. 
Boersma, M., Buckley, P. and Ghauri, P. (2003), Towards a model of trust in international joint venture relationships, Journal of Business Research, 56, 1031-1042.

Borys, B. \& Jemison, D. (1989). Hybrid arrangements as strategic alliances: theoretical issues in organisational combinations. Academy of Management Review, 14(2), 234-249.

Burgess, R. (1984). In the Field: An Introduction to Field Research. Allen and Unwin: London.

Cannon, J. \& Mullen, M. (1998). Understanding the influence of national culture on the development of trust. The Academy of Management Review, 23(3), 601-620.

Cater, T. and Cater, B. (2010). Product and relationship quality influence on customer commitment and loyalty in B2B manufacturing relationships. Industrial Marketing Management, $39(8), 1321-1333$.

Cova, B. \& Salle, R. (2000). Rituals in managing extra-business relationships in international project marketing: a conceptual framework. International Business Review, 9(6), 669-685.

Christopher, M., Payne, A. \& Ballantyne, D. (1991). Relationship Marketing. ButterworthHeinemann: London.

Crosby, L., Evans, K. \& Cowles, D. (1990). Relationship quality in services selling: an interpersonal perspective. Journal of Marketing, 54(3), 68-81. 
Czinkota, M., Ronkainen, I. \& Moffett, M. (1999). International Business, (5 ${ }^{\text {th }}$ ed.). The Dryden Press: London.

Das, T. \& Teng, B. (1998). Between trust and control: developing confidence in partner cooperation in alliances. Academy of Management Review, 23(3), 491-512.

Das, T. \& Teng, B. (2001). Trust, control, and risk in strategic alliances: An integrated framework. Organization Studies, 22(2): 251-283.

Dwyer, F., Schurr, P. \& Oh, S. (1987). Developing buyer-seller relationship. Journal of Marketing, 51(2), 11-27.

Einwiller, S. (2003). When reputation engender trust: an empirical investigation in business-tocommerce electronic commerce. Electronic Markets, 13(3), 196-209.

Fang, E., Palmatier, R., Scheer, L. \& Li, N. (2008). Trust at different organizational levels. Journal of Marketing, 72(March), 80-98.

Fletcher, G., Simpson, J. \& Thomas, G. (2000). The measurement of perceived relationship quality components: a confirmatory factor analytic approach. Personality and Social Psychological Bulletin, 26(3), 340-354. 
Fletcher, M. and Harris, S. (2012), Knowledge acquisition for the internationalization of smaller firms: Content and sources, International Business Review, 21/4, 631-647.

Fontana, A. \& Frey, J. (2000). The interview: from structured questions to negotiated text. In Denzin, N. and Lincoln, Y. Handbook of Qualitative Research, (2 ${ }^{\text {nd }}$ ed.). Sage Publication: Thousand Oaks, 645-672.

Ford, D. (1980). The development of buyer-seller relationships in industrial markets. European Journal of Marketing, 14(5/6), 339-353.

Ford, D., Gadde, L., Hakansson, H., Snehota, I., Turnbull, P. \& Wilson, D. (1998). Managing Business Relationships. John Wiley and Sons: Chichester.

Frazier, G. \& Rody, R. (1991). The use of influence strategies in interfirm relationships in industrial product channels. Journal of Marketing, 55(1), 52-69.

Ganesan, S. (1994). Determinants of long-term orientation in buyer-seller relationships. Journal of Marketing, 58(2), 1-19.

Gao, T., Sirgy, J. \& Bird, M. (2005). Reducing buyer decision-making uncertainty in organisational purchasing: can supplier trust, commitment, and dependence help? Journal of Business Research, 58(4), 397-405. 
Ghauri, P. (2004), Designing and conducting case studies in international business, in MarchanPiekkari, R., and Welch, C, (eds), Handbook of Qualitative Research for International Business, Cheltenham: Edward Elgar, 109-124.

Ghauri, P. and Gronhaug, K., (2010), Research Methods in Business Studies, $4^{\text {th }}$ Edition, London: Pearson.

Gronroos, C. (1994). From Marketing Mix to Relationship Marketing: Towards a Paradigm Shift in Marketing. Management Decision, 32(2), 4-20.

Gundlach, G. \& Murphy, P. (1993). Ethical and legal foundations of relational marketing exchanges. Journal of Marketing, 57(4), 35-46.

Gundlach, G., Achrol, R. \& Mentzer, J. (1995). The structure of commitment in exchange. Journal of Marketing, 59(1), 72-92.

Hakansson, H. (1982). International Marketing and Purchasing of Industrial Goods: An Interaction Approach. John Wiley and Sons: Chichester.

Halinen, A. (1997). Relationship Marketing in Professional Sector. Routledge: London.

Halinen, A. \& Tahtinen, J. (2002). A process theory of relationship ending. International Journal of Service Industry Management, 13(2), 163-180. 
Hall, E. (1973). The Silent Language. Doubleday: New York.

Harris, L., O’Malley, L. \& Patterson, M. (2003). Professional interaction: exploring the concept of attraction. Marketing Theory, 3(1), 9-36.

Hausman, A. \& Johnston, W. (2010). The impact of coercive and non-coercive forms of influence on trust, commitment, and compliance in supply chains. Industrial Marketing Management, 39 (3), 519-526.

Havila, V., Johanson, J. \& Thilenius, P. (2004). International business-relationship triads. International Marketing Review, 21(2), 172-186.

Hedaa, L. (1993). Distrust, uncertainties and disconfirmed expectations in supplier-customer relationships. International Business Review, 2(2), 191-206.

Heide, J. \& John, G. (1992). Do norms matter in marketing relationships? Journal of Marketing, $56(2), 32-44$.

Holstein, J. \& Gubrium, J. (2004). The active interview. In Silverman, D., Qualitative Research, ( $2^{\text {nd }}$ Ed.). Sage Publication: London. 
Jaros, S., Jermier, J., Koehler, J. \& Sincich, T. (1993). Effects of continuance, affective, and moral commitment on the withdrawal process: an evaluation of eight structural equation models. Academy of Management Journal, 36(5), 951-995.

Johnson, D. \& Grayson, K. (2005). Cognitive and affective trust in service relationships. Journal of Business Research, 58(4), 500-507.

Keh, H. \& Xie, Y. (2009). Corporate reputation and customer behavioral intentions: The roles of trust, identification and commitment. Industrial Marketing Management, 38(3), 732-742.

Kriz, A. \& Fang, T. (2003). Interpersonal trust in Chinese relational networks: moving from guanxi to xinre. IMP Conference, Lugano, Switzerland.

Laaksonen, T. Pajunen, K. \& Kulmala, H. (2008). Co-evaluation of trust and dependence in customer-supplier relationships. Industrial Marketing Management, 37(8), 910-920.

Lai, C., Pai, D., Yang, C. \& Lin, H. (2009). The effects of market orientation on relationship learning and relationship performance in industrial marketing: the dyadic perspectives. Industrial Marketing Management, 38 (3), 166-172.

Lehtonen, T. (2006). Collaborative relationships in facility services. Leadership \& Organisational Development Journal, 27(6), 429-437. 
Leonidou, L. (1996). Unveiling the marketing scene in Saudi Arabia: From sellers' to buyers' conditions. Journal of International Marketing and Marketing Research, 21(3), 123-144.

Levin, D. \& Cross, R. (2004). The strength of weak ties you can trust: the mediating role of trust in effective knowledge transfer. Management Science, 50(11), 1477-1490.

Levitt, T. (1983). The Marketing Imagination. The Free Press: New York, NY.

Li, L. (2005). The effects of trust and shared vision on inward knowledge transfer in subsidiaries' intra- and inter-organizational relationships. International Business Review, 14 (1): $77-95$.

Liu, Y., Li, Y., Tao, L. \& Wang, Y. (2008). Relationship stability, trust and relational risk in marketing channels: Evidence from China. Industrial Marketing Management, 37(3), 432-446.

Lui, S. \& Ngo, H. (2004). The role of trust and contractual safeguards on cooperation in nonequity alliances. Journal of Management, 30(4) 471-485.

Mayer, R., Davis, J. \& Schoorman, D. (1995). An integrative model of organisational trust. Academy of Management Review, 20(3), 709-734.

Meyer, J. \& Allen, N. (1991). A three-component conceptulisation of organiastional commitment. Human Resource Management Review, 1(1), 61-89. 
Michailova, S., \& Worm, V. (2003). Personal networking in Russia and China: Blat and Guanxi. European Management Journal, 21(4), 509-519.

Miles, M. \& Huberman, A. (1994). Qualitative Data Analysis, (2 ${ }^{\text {nd }}$ Ed.). Sage Publications: California, CA.

Miyamoto, T. \& Rexha, N. (2004). Determinants of three facets of customer trust a marketing model of Japanese buyer-supplier relationship. Journal of Business Research, 57(3), 321-319.

Moorman, C., Zaltman, G. \& Deshpande, R. (1992). Relationships between providers and users of market research: the dynamics of trust within and between organisations. Journal of Marketing Research, 29(3), 314-328.

Morgan, R. \& Hunt, S. (1994). The commitment-trust theory of relationship marketing. Journal of Marketing, 58(3), 20-38.

Miyamoto, T. \& Rexha, N. (2004). Determinants of three facets of customer trust a marketing model of Japanese buyer-supplier relationship. Journal of Business Research, 57(3), 321-319.

Nes, E., Solberg, C. \& Silkoset, R. (2007). The impact of national culture and communication on exporter-distributor relations and on export performance. International Business Review, 16(4), $405-424$ 
Nicholson, C., Compeau, L. \& Sethi, R. (2001). The role of interpersonal liking in building trust in long-term channel relationships. Academy of Marketing Science Journal, 29(1), 3-15.

Ohmae, K. (1989). The global logic of strategic alliances. Harvard Business Review, 67(2), 143154.

Parvatiyar, A. \& Sheth, J. (2000). The domain and conceptual foundations of relationship marketing. In Sheth, J. \& Parvatiyar, A., Handbook of Relationship Marketing. Sage Publications: London, 3-38.

Pimpa, N. (2008). Relationship value in Thai business-to-business marketing, Journal of AsiaPacific Business, 9(3), 235-247

Pressey, A. \& Mathews, B. (2003). Jumped, pushed or forgotten? Approaches to dissolution. Journal of Marketing Management, 19(1/2), 131-155.

Rao, S. \& Perry, C. (2002). Thinking about relationship marketing: where are we now? Journal of Business \& Industrial Marketing, 17(7), 598-614.

Rempel, J., Holmes, J. \& Zanna, M. (1985). Trust in close relationships. Journal of Personality and Social Psychology, 49(1), 95-112. 
Ripolles, M., Blesa, A. and Monferrer, D. (2012), Factors enhancing the choice of higher resource commitment entry modes in international new ventures, International Business Review, 21/4, 648-666.

Rodriguez, C. \& Wilson, D. (1995). Trust me!!!... but how? Pennsylvania State University Park: Institute for the Study of Business Markets.

Rodriguez, C. \& Wilson, D. (2002). Relationship bonding and trust as a foundation for commitment in U.S.-Mexican strategic alliances: a structural equation modelling approach. Journal of International Marketing, 10(4), 53-76.

Rylander, D., Strutton, D. \& Pelton, L. (1997). Toward a synthesized framework of relational commitment: implications for marketing channel theory and practice. Journal of Marketing Theory and Practice, 5(2), 1-14.

Sandelowski, M. (1995). Qualitative analysis: what it is and how to begin. Research in Nursing and Health, 18, 371-375.

Sandy, J. \& Ganesan, S. (2000). Control mechanisms and the relationship life cycles: implication for safeguarding specific investments and developing commitment. Journal of Marketing Research, 37(2), 227-245. 
Seshadri, S. \& Mishra, R. (2004). Relationship marketing and contract theory. Industrial Marketing Management, 33(6), 513-526.

Sheaves, D. \& Barnes, J. (1996). The fundamentals of relationships: an exploration of the concept to guide marketing implementation. In Swartz, T., Bowen, D. and Brown, S. (Eds.), Advances in Services Marketing and Management Research and Practice. JAI Press: Greenwich, CT, 5, 215-45.

Sheth, J. \& Parvatiyar, A. (1995). The Evolution of Relationship Marketing. International Business Review, 4(4), 397-418.

Sinkovics, R., Penz, E. and Ghauri, P. (2008), Enhancing the trustworthiness of interview based qualitative research, Management International Review, 48/6, 689-714.

Sivaramakrishnan, S., Zhang, D., Delbaere, M. \& Bruning, E. (2008). The relationship between organizational commitment and market orientation. Journal of Strategic Marketing, 16(1), 55-73.

Smith, B. (1999). Selling Partner Relationships: The Role of Interdependence and Relative Influence. The Journal of Personal Selling \& Sales Management, 19(4), 21-40.

Smith, J. \& Barclay, D. (1997). The effects of organisational differences and trust on the effectiveness of selling partner relationships. Journal of Marketing, 61(1), 3-21. 
Stanton, W. (2002). The dimensions of stage theories. Current Psychology, 21(2), 176-198.

Svensson, G. (2005). Mutual and interactive trust in business dyadic: conditions and process. European Business Review, 17(5), 411-427.

Van de Ven, A. (1992). Suggestions for studying strategy process: a research note. Strategic Management Journal, 13, 169-188.

Vandenberghe, C. \& Tremblay, M. (2008). The role of pay satisfaction and organizational commitment in turnover intentions: a two-sample study. Journal of Business and Psychology, $22(3), 275-286$.

Walther, J. \& Bunz, U. (2005). The Rules of virtual groups: trust, liking, and performance in computer-mediated communication. Journal of Communication, 55(4), 828-846.

Wang, C. (2007). Guanxi vs. relationship marketing: Exploring underlying differences. Industrial Marketing Management, 36(1) 81-86.

Wang, C., Siu, N. \& Barnes, B. (2008). The significance of trust and renqing in the long-term orientation of Chinese business-to-business relationships. Industrial Marketing Management, $37(7), 819-824$. 
Weitz, B. \& Jap, S. (1995). Relationship marketing and distribution channels. Journal of the Academy of Marketing Science, 23(4), 305-320.

Wicks, A., Shawn, B. \& Thomas, J. (1999). The structure of optimal trust: moral and strategic implications. Academy of Management Review, 24(1), 99-116.

Williams, J., Han, S. \& Qualls, W. (1998). A conceptual model and study of cross-cultural business relationships. Journal of Business Research, 42(2), 135-143.

Wilson, D. (1995). An Integrated Model of Buyer-Seller Relationships. Journal of the Academy of Marketing Science, 23(4), 335-346.

Wuyts, S. \& Geyskens, I. (2005). The formation of buyer-supplier relationships: detailed contract drafting and close partner selection. Journal of Marketing, 69(4), 103-117.

Yau, O., Lee, J., Chow, R., Sin, L. \& Tse, A. (2000). Relationship marketing the Chinese way. Business Horizons, 43(1), 16-24.

Zabkar, V. \& Brencic, M. (2004). Values, trust, and commitment in business-to-business relationships: a comparison of two former Yugoslav markets. International Marketing Review, $21(2), 202-215$. 
Zaheer, A. \& Venkatraman, V. (1995). Relational governance as an interorganisational strategy:

an empirical test of the role of trust in economic exchange. Strategic Management Journal, 16,

223-248.

Appendix A: Summary of Models/Frameworks of Relationship Development

\begin{tabular}{|c|c|c|c|}
\hline & Author(s) & Relationship Development & Focus \\
\hline \multirow{6}{*}{ 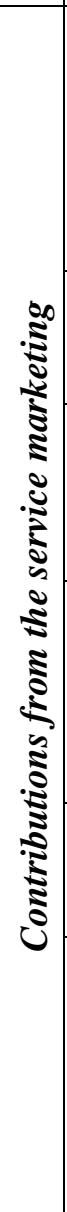 } & $\begin{array}{l}\text { Gummesson } \\
\text { (1979) }\end{array}$ & $\begin{array}{l}\text { Pre-stage } \\
\text { Decision process } \\
\text { Decision to select a particular } \\
\text { professional } \\
\text { Operation of the assignment } \\
\text { Post-stage }\end{array}$ & $\begin{array}{l}\text { Buyer-seller interaction (professional } \\
\text { service context) }\end{array}$ \\
\hline & $\begin{array}{l}\text { Gronroos } \\
(1980)\end{array}$ & $\begin{array}{l}\text { Initial stage (create interest) } \\
\text { Purchasing process } \\
\text { Consumption process }\end{array}$ & $\begin{array}{l}\text { Customer relation (marketing } \\
\text { planning) }\end{array}$ \\
\hline & $\begin{array}{c}\text { Wackman } \\
\text { et al. } \\
(1986 / 1987)\end{array}$ & $\begin{array}{l}\text { Pre-relationship phase } \\
\text { Development phase } \\
\text { Maintenance phase } \\
\text { Termination phase }\end{array}$ & Agency-client relationship \\
\hline & York (1990) & $\begin{array}{l}\text { Ignorance } \\
\text { Interest } \\
\text { Initiation } \\
\text { Involvement } \\
\text { Integration } \\
\end{array}$ & $\begin{array}{l}\text { Supplier-client relationship } \\
\text { (professional service) }\end{array}$ \\
\hline & $\begin{array}{c}\text { Palmer and } \\
\text { Bejou } \\
(1994)\end{array}$ & $\begin{array}{l}\text { Sales orientation/selling pressure } \\
\text { Ethics } \\
\text { Empathy }\end{array}$ & $\begin{array}{l}\text { Buyer-seller relationship } \\
\text { (investment service sector) }\end{array}$ \\
\hline & $\begin{array}{l}\text { Halinen } \\
(1997)\end{array}$ & $\begin{array}{l}\text { Pre-relationship phase } \\
\text { Initial phase } \\
\text { Growth phase } \\
\text { Decline phase } \\
\text { Constant phase } \\
\text { Troubled phase }\end{array}$ & Advertising agency-client relationship \\
\hline
\end{tabular}




\begin{tabular}{|c|c|c|c|}
\hline \multirow{9}{*}{ 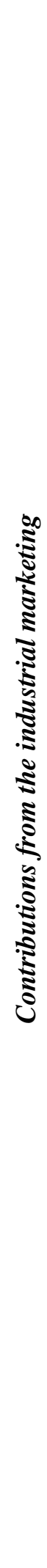 } & $\begin{array}{l}\text { Van de Ven } \\
\text { (1976) }\end{array}$ & $\begin{array}{l}\text { Situational factors } \\
\text { Resource dependence; } \\
\text { Commitment to problem issue/opportunity; } \\
\text { Awareness; Consensus; Domain Similarity } \\
\text { Process Dimensions } \\
\text { Intensity of resource flow; } \\
\text { Intensity of information flow } \\
\text { Structural Dimensions } \\
\text { Formalisation of IR; } \\
\text { Centralisation of IR; } \\
\text { Complexity of IR } \\
\text { Outcome Dimensions } \\
\text { Perceived effectiveness }\end{array}$ & Inter-agency networks relationship \\
\hline & $\begin{array}{l}\text { Ford (1980; } \\
1982)\end{array}$ & $\begin{array}{l}\text { Pre-relationship stage } \\
\text { Early stage } \\
\text { Development stage } \\
\text { Long-term stage } \\
\text { Final stage }\end{array}$ & Buyer-seller relationship \\
\hline & $\begin{array}{l}\text { Ford and } \\
\text { Rosson } \\
\text { (1982); } \\
\text { Rosson } \\
(1986)\end{array}$ & $\begin{array}{l}\text { New } \\
\text { Growing } \\
\text { Troubled } \\
\text { Static } \\
\text { Inert } \\
\end{array}$ & $\begin{array}{c}\text { Manufacturer-overseas distributor } \\
\text { relationship }\end{array}$ \\
\hline & $\begin{array}{l}\text { Levitt } \\
(1983)\end{array}$ & $\begin{array}{l}\text { Meeting } \\
\text { Going out } \\
\text { Romance } \\
\text { Marriage } \\
\text { Divorce } \\
\end{array}$ & Buyer-seller relationship \\
\hline & $\begin{array}{l}\text { Frazier } \\
(1983)\end{array}$ & $\begin{array}{l}\text { Initiation process } \\
\text { Implementation process } \\
\text { Review process }\end{array}$ & $\begin{array}{l}\text { Inter-organisational exchange } \\
\text { behaviour }\end{array}$ \\
\hline & $\begin{array}{l}\text { Wilson and } \\
\text { Mummalan- } \\
\text { eni (1986) }\end{array}$ & $\begin{array}{l}\text { Need complementarity } \\
\text { Interactions } \\
\text { Outcomes } \\
\text { Satisfaction } \\
\text { Investments } \\
\text { Commitment }\end{array}$ & Buyer-seller relationship \\
\hline & $\begin{array}{l}\text { Dwyer et al. } \\
\quad(1987)\end{array}$ & $\begin{array}{l}\text { Phase } 1 \text { awareness } \\
\text { Phase } 2 \text { exploration } \\
\text { Phase } 3 \text { expansion } \\
\text { Phase } 4 \text { commitment } \\
\text { Phase } 5 \text { dissolution }\end{array}$ & Buyer-seller relationships \\
\hline & $\begin{array}{l}\text { Frazier et } \\
\text { al. }(1988)\end{array}$ & $\begin{array}{l}\text { Interest stage } \\
\text { Initiation-rejection stage } \\
\text { Implementation stage } \\
\text { Review stage }\end{array}$ & $\begin{array}{l}\text { Supplier-customer just-in-time } \\
\text { exchange relationships }\end{array}$ \\
\hline & $\begin{array}{l}\text { Borys and } \\
\text { Jemison } \\
(1989)\end{array}$ & $\begin{array}{l}\text { Hybrid purpose } \\
\text { Boundary definition } \\
\text { Value creation } \\
\text { Hybrid stability }\end{array}$ & Strategic alliances \\
\hline
\end{tabular}




\begin{tabular}{|c|c|l|}
\hline $\begin{array}{c}\text { Ring and } \\
\text { Van de Ven } \\
(1994)\end{array}$ & $\begin{array}{l}\text { Negotiation stage } \\
\text { Commitment stage } \\
\text { Execution stage }\end{array}$ & $\begin{array}{c}\text { Co-operative inter-organisational } \\
\text { relationships }\end{array}$ \\
\hline $\begin{array}{c}\text { Morgan and } \\
\text { Hunt (1994) }\end{array}$ & $\begin{array}{l}\text { Antecedents variables } \\
\text { Mediating variables } \\
\text { Consequences variables }\end{array}$ & $\begin{array}{c}\text { Relationship development (tyre } \\
\text { industry) }\end{array}$ \\
\hline \multirow{2}{*}{$\begin{array}{l}\text { Wilson } \\
(1995)\end{array}$} & $\begin{array}{l}\text { Pefiner selection } \\
\text { Setting relationship boundaries } \\
\text { Creating relationship value } \\
\text { Relationship maintenance }\end{array}$ & Buyer-seller relationship \\
\hline $\begin{array}{c}\text { Ford } \text { et al. } \\
(1998)\end{array}$ & $\begin{array}{l}\text { Pre-relationship stage } \\
\text { Exploratory stage } \\
\text { Developing stage } \\
\text { Stable stage }\end{array}$ & Buyer-seller relationship \\
\hline \multirow{2}{*}{$\begin{array}{l}\text { Zineldin } \\
(2002)\end{array}$} & $\begin{array}{l}\text { Discovery phase (romance) } \\
\text { Development phase (engagement) } \\
\text { Commitment phase (marriage) } \\
\text { Loyalty phase (old-married) }\end{array}$ & Strategic business relationship \\
\hline $\begin{array}{c}\text { Laaksonen, } \\
\text { et al. } \text { (2008) }\end{array}$ & $\begin{array}{l}\text { Screening stage } \\
\text { Commitment stage } \\
\text { Mature stage }\end{array}$ & Customer-supplier relationship \\
\hline
\end{tabular}


